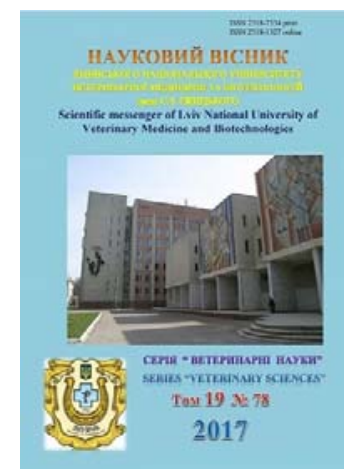

Науковий вісник Львівського національного університету ветеринарної медицини та біотехнологій імені С.З. Гжицького

Scientific Messenger of Lviv National University of Veterinary Medicine and Biotechnologies

doi:10.15421/nvlvet7836

ISSN 2518-7554 print

ISSN 2518-1327 online

$\underline{\text { http://nvlvet.com.ua/ }}$

УДК 619:616.008.9:636.2

\title{
Застосування неорганічних та органічних сполук Сo, Cu та Zn за їх недостатності у дійних корів
}

\author{
Л.Г. Слівінська, В.І. Русин, І.А. Максимович, М.І. Леньо, Б.О. Чернушкін, О.І. Приступа \\ rusin_v@ukr.net
}

Львівський національний університет ветеринарної медицини та біотехнологій імені С.3. Гжицького, вул. Пекарська, 50, м. Львів, 79010, Украӥна

Наведено результати досліджень окремих біохімічних показників крові у дійних корів за профілактики недостатності Co, Cu та Zn неорганічними та органічними сполуками мікроелементів. Мета роботи - дослідити стан окремих біохімічних показників крові у дійних корів при застосуванні неорганічних та органічних сполук Со, Си та Zn за профілактики їх недостатності. Матеріалом для досліджень була сироватка крові дослідних тварин, де визначали: вміст загального білку та відсоткове відношення альбумінів, вміст загального кальцію, неорганічного фосфору, активність аспартатамінотрансферази (АСТ), аланінамінотрансферази (АЛТ), лужної фосфатази (ЛФ).

Для проведення досліджень дійним коровам периої дослідної групи разом з кормами основного раціону згодовували суміш сульфатів мікроелементів у наступному співвідноменні компонентів (мг/100 кг маси тіла): $\mathrm{CuSO}_{4}-50, \mathrm{CoSO}_{4}-5$, $\mathrm{ZnSO}_{4}$ - 120. Тваринам другої дослідної групи згодовували суміш метіонатів і лізинатів мікроелементів у наступному співвідношенні компонентів (мг/100 кг маси тіла): CuMet-15, CuLis - 15, CoMet - 1, CoLis - 1, ZnMet - 35, ZnLis - 35. 3zодовування суміші сполук дефіцитних мікроелементів проводилось шляхом змішування їх з комбікормом, один раз на добу, протягом 60 днів. Очінку результатів досліджень проводили на початку та в кінці досліду.

На фоні дефіциту Кобальту, Купруму та Цинку, у клінічно хворих тварин встановлено гіпопротеїнемію, гіпоальбумінемію, гіпокальиіємію, підвищену активність АСТ, АЛТ та ЛФ, щзо свідчать про порушення обміну речовин у дійних корів та розвиток мікроелементозів.

Встановлено, щуо застосування дійним коровам хелатних сполук у вигляді метіонатів та лізинатів дефіцитних мікроелементів мало кращий терапевтичний ефект порівняно із неорганічними сполуками. Результатом застосування хелатних сполук мікроелементів було вірогідне збільшення вмісту загального білка сироватки крові, фракції альбумінів, загального кальиію, зниження активності АСТ, АЛТ та ЛФ.

Ключові слова: дійні корови, мікроелементна недостатність, загальний білок, альбуміни, загальний кальцій, неорганічний фосфор, ферменти, профілактика, хелатні сполуки, метіонати, лізинати.

\section{Применение неорганических и органических соединений Сo, Cu Ta Zn при их недостаточности у дойных коров}

\author{
Л.Г. Сливинская, В.И. Русин, И.А. Максимович, М.И. Леньо, Б.О. Чернушкин, О.И. Приступа \\ rusin_v@ukr.net
}

Львовский национальный университет ветеринарной медициныь и биотехнологий имени С.3. Гжицякого, ул. Пекарская, 50, г. Львов,79010, Украина

\begin{abstract}
Приведены результаты исследований отдельных биохимических показателей крови у дойных коров за профилактики недостаточности Со, Си и Zn неорганическими и органическими соединениями микроэлементов. Цель работь - исследовать состояние отдельных биохимических показателей крови у дойных коров при применении неорганических и органических соединений Со, Си и Zn за профилактики их недостаточности. Материалом для исследований была сыворотка крови
\end{abstract}

\section{Citation:}

Slivinska, L.G., Rusyn, V.I., Maksymovych, I.A., Leno, M.I., Chernushkin, B.O., Prystupa, O.I. (2017). Application of inorganic and organic compounds $\mathrm{Co}, \mathrm{Cu}$ and $\mathrm{Zn}$ due to their lack of dairy cows. Scientific Messenger LNUVMB, 19(78), 177-181. 
опытных животных, где определяли: содержание общего белка и процентное отношение альбуминов, содержание общего кальция, неорганического фосфора, активность аспартатаминотрансферазы (АСТ), аланинаминотрансферазь (АЛТ), шелочной фосфатазы (ЩФ).

Для проведения исследований дойным коровам первой опытной группы вместе с кормами основного рациона скармливали смесь сульфатов микроэлементов в следующем соотношении компонентов (мг/100 кг массы тела): $\mathrm{CuSO}_{4}-50$, $\mathrm{CoSO}_{4}-$ 5, $\mathrm{ZnSO}_{4}-120$. Животным второй опытной группы скармливали смесь метионатов и лизинатов микроэлементов в следующем соотношении компонентов (ма/100 кг массы тела): CuMet - 15 CuLis - 15 CoMet - 1, CoLis - 1, ZnMet - 35, ZnLis 35. Скармливание смеси соединений дефицитных микроэлементов проводилось путем смешивания их с комбикормом один раз в сутки, в течении 60 дней. Оценку результатов исследований проводили в начале и в конце опьта.

На фоне дефицита Кобальта, Меди и Цинка, в клинически больных животных установлено гипопротеинемию, гипоальбуминемию, гипокальциемии, повыщенную активность АСТ, АЛТ и ЩФ, свидетельствующие о нарушении обмена веществ у дойных коров и развитие микроэлементозов.

Установлено, что применение дойным коровам хелатных соединений в виде метионатов и лизинатов дефицитных микроэлементов мало лучший терапевтический эффект по сравнению с неорганическими соединениями. Результатом применения хелатных соединений микроэлементов было достоверное увеличение содержания общего белка сыворотки крови, фракции альбуминов, общего кальция, снижение активности АСТ, АЛТ и ЩФ.

Ключевые слова: дойные коровы, микроэлементная недостаточность, общчий белок, альбумины, общций кальций, неорганический фосфор, ферменты, профилактика, хелатные соединения, метионаты, лизинатьл.

\title{
Application of inorganic and organic compounds $\mathrm{Co}, \mathrm{Cu}$ and $\mathrm{Zn}$ due to their lack of dairy cows
}

\author{
L.G. Slivinska, V.I. Rusyn, I.A. Maksymovych, M.I. Leno, B.O. Chernushkin, O.I. Prystupa \\ rusin_v@ukr.net
}

Stepan Gzhytskyi National University of Veterinary Medicine and Biotechnologies Lviv, Pekarska Str., 50, Lviv, 79010, Ukraine

The results of research of certain biochemical parameters of blood in dairy cows for the prevention of insufficiency of Co, Cu and $\mathrm{Zn}$ by inorganic and organic compounds of trace elements are presented. The purpose of the work - to investigate the state of individual biochemical parameters of blood in dairy cows when using inorganic and organic compounds Co, Cu and Zn to prevent their insufficiency. The research material was the blood serum of experimental animals, which determined the content of total protein and the percentage of albumin, total calcium content, inorganic phosphorus, aspartateaminotransferase (AST) activity, alanineaminotransferase (ALT), alkaline phosphatase (AP).

For research on dairy cows of the first experimental group, together with the feeds of the main diet, a mixture of trace elements sulphates was fed in the following ratio of components (mg/100 kg body weight): $\mathrm{CuSO}_{4}-50, \mathrm{CoSO}_{4}-5, \mathrm{ZnSO}_{4}-120$. Animals of the second experimental group fed a mixture of methionates and lysinates of trace elements in the following ratio of components (mg/ $100 \mathrm{~kg}$ of body weight): CuMet-15, CuLis-15, CoMet-1, CoLis-1, ZnMet-35, ZnLis-35. Feeding the mixture of compounds of fragile microelements was carried out by mixing them with mixed fodder, once a day, for 60 days. The evaluation of the research results was carried out at the beginning and at the end of the experiment.

On the background of the deficit of Cobalt, Cuprum and Zinc, clinically diseased animals have hypoproteinemia, hypoalbuminemia, hypocalcemia, increased activity of AST, ALT and AP, indicating a metabolic abnormality in cows and development of microelementosis. It was established that the use of chelated cheeses in the form of methionates and lysinates of scarce microelements had a better therapeutic effect compared to inorganic compounds. The result of the application of chelate compounds of trace elements was a possible increase in the content of total protein in the blood serum, fractions of albumins, total calcium, decrease in the activity of AST, ALT and AP.

Key words: dairy cows, microelement insufficiency, total protein, albumin, total calcium, inorganic phosphorus, enzymes, prophylaxis, chelate compounds, methionates, lysinates.

\section{Вступ}

Здоров’я та продуктивність тварин залежить від забезпеченості раціону біотичними мікроелементами, які $є$ структурними компонентами білків, вітамінів, ферментів або є їх активаторами і відіграють важливу роль в окисно-відновних процесах організму (Zaharenko et al., 2004; Vlizlo et al., 2006; Kuchinskij, 2007).

Нестача або дисбаланс біотичних мікроелементів у грунтах, водних джерелах та рослинах супроводжується їх дефіцитом і в організмі тварин, що призводить до порушення окисно-відновних процесів, зниження резистентності, низької продуктивності та розвитку мікроелементозів. Останні зустрічаються в біогеохімічних зонах і провінціях України (Sudakov, 1995, Gurs'kyj, 2006; Dolec'kyj, 2007).
У тваринницьких господарствах для забезпечення тварин мікроелементами використовують їх неорганічні сполуки у вигляді солей або карбонатів, проте вони не дають очікуваного ефекту у зв'язку з їхньою низькою біодоступністю (1-25\%), у великих дозах токсичністю, а також, утворенням нерозчинних комплексів (Grygorjeva et al., 1998; Kuznecov and Kalashnik, 2002; Bokova, 2008).

Актуальним залишається питання розробки ефективних способів забезпечення тварин дефіцитними мікроелементами за їх нестачі. Одним із таких способів $є$ застосування хелатів мікроелементів, які являють собою найефективнішу форму взаємодії металу 3 лігандами. У сполуці з органічними речовинами активність мікроелементів зростає в сотні тисяч разів по- 
рівняно з їх іонним станом в організмі тварин (Kebec, 1998; Bojkiv et al., 2001).

Згідно даних (Mel'nychenko and Gerasymenko, 1994; Lowel et al., 1994; Tako et al., 2004) встановлено, що всмоктування мікроелементів через стінку кишечника проходить у вигляді протеїнатів хелатів двовалентних металів з гідролізатами білка та амінокислотами. У такому вигляді мікроелменти легко проникають через стінку кишечнику, завдяки чому їх засвоюваність становить 95-100\%.

Дослідженнями (Kinal et al., 2005; Kravciv et al., 2008; Slivins'ka, 2008; Bereza et al., 2010; Koltun and Rusyn, 2014) встановлено, що застосування хелатних комплексів на основі однієї з амінокислот позитивно впливало на окисно-відновні процеси в організмі і продуктивність тварин. Однак, науковообгрунтованих даних щодо застосування продуктивним тваринам хелатного комплексу, в складі якого були б одночасно дві хелатні сполуки в наявній науковій літературі обмаль.

Мета роботи - дослідити стан окремих біохімічних показників крові у дійних корів при застосуванні неорганічних та органічних сполук $\mathrm{Co}, \mathrm{Cu}$ та $\mathrm{Zn}$ за профілактики їх недостатності.

\section{Матеріал та методи досліджень}

Дослідження проводились на базі ПАФ «Нефедівське» Кам'янець-Подільського району Хмельницької області. Об'єктом досліджень були дійні корови $(\mathrm{n}=16)$, чорно-рябої породи, віком 4-6 років та добовим надоєм 16-18 л молока. Утримання тварин у господарстві прив'язне, годівля триразова, згідно з раціоном, з урахуванням маси тіла тварин та добового надою.

Матеріалом для досліджень була сироватка крові дійних корів, де визначали: вміст загального білку та відсоткове відношення альбумінів, вміст загального кальцію, неорганічного фосфору, активність аспартатамінотрансферази (АСТ), аланінамінотрансферази (АЛТ), лужної фосфатази (ЛФ). Дані показники визначали на напівавтоматичному біохімічному аналізаторі типу «Humalyzer 2000» (Німеччина).
Для проведення досліджень нами було сформовано дві дослідні групи тварин, по 8 голів у кожній. При цьому, дійним коровам першої дослідної групи разом 3 кормами основного раціону згодовували суміш неорганічних сполук мікроелементів у вигляді їх солей (мг/100 кг маси тіла): $\mathrm{CuSO}_{4}-50, \mathrm{CoSO}_{4}-5, \mathrm{ZnSO}_{4}-$ 120. Тваринам другої дослідної групи згодовували суміш метіонатів і лізинатів мікроелементів у наступному співвідношенні компонентів (мг/100 кг маси тіла): CuMet $-15, \mathrm{CuLis}-15$, CoMet -1 , CoLis -1 , ZnMet - 35, ZnLis - 35. Згодовування суміші сполук дефіцитних мікроелементів проводилось шляхом змішування їх з комбікормом, один раз на добу, протягом 60 днів. Оцінку результатів досліджень проводили на початку та в кінці досліду.

\section{Результати та їх обговорення}

Згідно даних попередніх досліджень (Koltun and Rusyn, 2016) у дійних корів реєстрували: в'ялість, зниження та спотворення апетиту, тьмяність і скуйовдженість волосяного покриву, енофтальм, анемічність видимих слизових оболонок, часткову депігментацію волосяного покриву у вигляді так званих «окулярів», зниження тургору шкіри, її потовщеність та сухість, зниження кількості жуйних періодів та гіпотонію передшлунків, а також зниження молочної продуктивності. У сироватці крові клінічно хворих дійних корів було встановлено низький вміст Купруму $(6,61 \pm 0,40$ мкмоль/л) та Цинку $(8,92 \pm$ 0,74 мкмоль/л), а у 37,5\% дослідних тварин - Кобальту $(0,26 \pm 0,04$ мкмоль/л). Разом з цим у хворих тварин відмічали гіперфосфатемію, гіпопротеїнемію, гіпоальбумінемію, а також високу активність АСТ, АЛТ та ЛФ, що свідчить про порушення окисновідновних процесів.

Згідно результатів наших досліджень (табл.) встановлено підвищення вмісту загального білка в сироватці крові у дійних корів першої дослідної групи на 25,9\% (Р < 0,001), другої - на 35,2\% (Р < 0,001) відносно початку досліду. При цьому, у тварин другої дослідної групи вміст загального білка був вищим на $8,7 \%$ (Р < 0,05) порівняно з першою.

Таблицяя

Деякі біохімічні показники крові дійних корів, $(\mathrm{n}=16)$

\begin{tabular}{|c|c|c|c|c|c|}
\hline \multirow{2}{*}{ Показники } & \multirow{2}{*}{$\begin{array}{l}\text { Біометричні } \\
\text { показники }\end{array}$} & \multicolumn{2}{|c|}{ Початок досліду } & \multicolumn{2}{|c|}{ Кінець досліду } \\
\hline & & I дослідна & II дослідна & I дослідна & II дослідна \\
\hline \multirow{2}{*}{ Загальний білок, г/л } & Lim & $53,4-59,8$ & $54,0-60,6$ & $65,0-80,4$ & $74,1-84,0$ \\
\hline & $\mathrm{M} \pm \mathrm{m}$ & $56,7 \pm 0,82$ & $57,4 \pm 0,76$ & $71,4 \pm 1,96 * * *$ & $77,6 \pm 1,60 * * * / x$ \\
\hline \multirow{2}{*}{ Альбуміни, \% } & Lim & $28,4-33,6$ & $28,9-34,0$ & $36,4-41,7$ & $38,7-46,3$ \\
\hline & $\mathrm{M} \pm \mathrm{m}$ & $31,1 \pm 0,69$ & $31,7 \pm 0,66$ & $38,4 \pm 0,65 * * *$ & $42,8 \pm 1,04 * * * / x x$ \\
\hline \multirow{2}{*}{ Са, ммоль/л } & Lim & $2,2-2,6$ & $2,2-2,7$ & $2,0-2,8$ & $2,2-3,1$ \\
\hline & $\mathrm{M} \pm \mathrm{m}$ & $2,4 \pm 0,05$ & $2,5 \pm 0,06$ & $2,5 \pm 0,10$ & $2,7 \pm 0,11$ \\
\hline \multirow{2}{*}{ Р, ммоль/л } & Lim & $3,0-3,5$ & $3,0-3,6$ & $1,6-2,4$ & $1,4-2,1$ \\
\hline & $\mathrm{M} \pm \mathrm{m}$ & $3,3 \pm 0,06$ & $3,2 \pm 0,07$ & $2,1 \pm 0,11 * * *$ & $1,7 \pm 0,10^{* * * / x}$ \\
\hline \multirow{2}{*}{ АСТ, од/л } & Lim & $57,2-79,3$ & $56,5-78,8$ & $42,1-61,8$ & $36,3-54,8$ \\
\hline & $\mathrm{M} \pm \mathrm{m}$ & $68,3 \pm 2,75$ & $67,7 \pm 2,78$ & $52,0 \pm 2,38 * * *$ & $44,3 \pm 2,58 * * * / x$ \\
\hline \multirow{2}{*}{ АЛТ, од/л } & Lim & $29,1-38,3$ & $28,2-37,4$ & $20,9-33,6$ & $17,5-30,9$ \\
\hline & $\mathrm{M} \pm \mathrm{m}$ & $34,2 \pm 1,10$ & $33,1 \pm 1,15$ & $27,4 \pm 1,59 * *$ & $24,5 \pm 1,68 * * *$ \\
\hline \multirow{2}{*}{ ЛФ, од/л } & Lim & $349,1-464,8$ & $337,2-450,4$ & $176,2-268,4$ & $158,0-232,8$ \\
\hline & $\mathrm{M} \pm \mathrm{m}$ & $399,0 \pm 15,01$ & $386,8 \pm 14,36$ & $226,7 \pm 10,86^{* * *}$ & $192,0 \pm 9,62 * * * / x$ \\
\hline
\end{tabular}

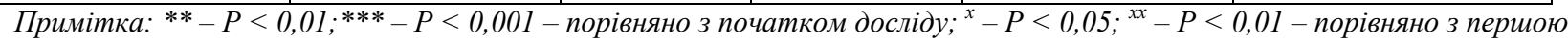
дослідною групою. 
Підвищення вмісту загального білка сироватки крові супроводжувалось змінами у співвідношенні його фракцій. Так, після закінчення досліду встановлено підвищення альбумінів у тварин першої групи на $7,3 \%(\mathrm{P}<0,001)$ проте їх кількість залишалася нижчою за нижню межу фізіологічних коливань (табл.). У тварин другої дослідної групи кількість альбумінів зросла відносно початку досліду на $11,1 \%$ ( $<0,001)$ та була вищою на $4,4 \%(\mathrm{P}<0,01)$ порівняно 3 першою. Зростання вмісту загального білка та альбумінів пов'язано з відновлення гепатоцитів та нормалізацію білоксинтезувальної функції печінки за мікроелементної підгодівлі хворих тварин (Yefimov, 2004; Kljuchkovs'ka, 2004).

Вміст загального кальцію (табл.) у сироватці крові тварин після закінчення експерименту вірогідно не різнився між дослідними групами і знаходився в межах фізіологічних коливань. Натомість після 60денної мікроелементної підгодівлі встановлено зниження вмісту неорганічного фосфору у першій дослідній групі на 36,4\% (P < 0,001), другій - на 53,1\% $(\mathrm{P}<0,001)$. При цьому, вміст неорганічного фосфору у другій дослідній групі був вірогідно $(\mathrm{P}<0,05)$ нижчим на 19,0\% порівняно з першою. Зниження до норми вмісту неорганічного фосфору у сироватці крові хворих тварин ймовірно пов'язано 3 ослабленням процесів остеолізису та реабсорбції фосфору у ниркових канальцях (Dolec'kyj, 2013).

Застосування мікроелементної підгодівлі сприяло нормалізації активності трансаміназ та ЛФ, проте 3 деякою відмінністю між групами. Так, по закінченню досліду у першій дослідній групі встановлено зниження активності АСТ і АЛТ на 23,6 (Р < 0,001) i 19,9 \% (Р < 0,01) відповідно (табл.). Проте, показник АСТ залишався вищим відносно верхньої межі фізіологічних коливань, що ймовірно пов'язано з недостатнім відновленням клітинних мембран гепатоцитів. У другій дослідній групі встановлено зниження активності АСТ і АЛТ на 34,6\% (Р<0,001) та 26,0\% (P $<0,001)$ відносно початку досліду. При цьому, активність АСТ була вірогідно $(\mathrm{P}<0,05)$ нижчою на 14,2\% порівняно 3 тваринами першої дослідної групи. Зниження активності трансаміназ у дійних корів другої дослідної групи пов'язано з відновленням структури та функції гепатоцитів, що очевидно є наслідком позитивного впливу комплексу халатних сполук мікроелементів (Skyba et al., 2009).

Активність ЛФ знизилась у першій дослідній групі на 43,2\% (Р < 0,001), проте залишалась вищою за верхню межу фізіологічних коливань. У другій дослідній групі після закінчення досліду у 37,5\% дослідних тварин активність ЛФ ще залишалась високою, проте в середньому по групі знизилась на 50,4\% (P < 0,001) та була нижчою на $15,3 \%(\mathrm{P}<0,05)$ порівняно 3 першою. Таке зниження активності ЛФ пов'язано з відновленням клітинних мембран паренхіми печінки та нормалізації активності остеокластів (Dresler et al., 2016).

Підсумовуючи результати біохімічних досліджень крові, необхідно відзначити, що застосування дійним коровам другої дослідної групи комплексу метіонатів та лізинатів біогенних мікроелементів забезпечило кращий терапевтичний ефект по всіх біохімічних показниках крові, порівняно із застосуванням неорганічних сполук.

\section{Висновки}

1. У хворих дійних корів встановлено гіпопротеїнемію, гіпоальбумінемію, гіперфосфатемію, підвищення активності трансаміназ та лужної фосфатази на фоні мікроелементної недостатності.

2. Застосування хворим дійним коровам неорганічних і органічних сполук дефіцитних мікроелементів сприяло нормалізації окремих біохімічних показників крові за профілактики мікроелементної недостатності.

3. Кращий терапевтичний ефект встановлено у другій дослідній групі, тваринам якої застосовували метіонати та лізинати дефіцитних мікроелементів.

Перспективи подальших досліджень. Дослідження щодо впливу комплексу хелатних сполук $\mathrm{Co}, \mathrm{Cu}$ та $\mathrm{Zn}$ на процеси антиоксидантного захисту в організмі дійних корів за профілактики мікроелементної недостатності.

\section{Бібліографічні посилання}

Bereza, V.I., Golopura, S.I., Cvilihovs'kyj, M.I. (2010). Zastosuvannja tvarynam helatnyh spoluk biogennyh mikroelementiv z profilaktychnoju i likuval'noju metoju. Zb. nauk. prac HDZA. Harkiv. 22(1), 211215 (in Ukrainian).

Bojkiv, D.P., Svystun, Yu.D., Fartushok, N.V. (2001). Mikroelementy: dosjagnennja i perspektyvy. Eksperymental'na klinichna fiziologija ta biohimija. 2, 124-128 (in Ukrainian).

Bokova, T.P. (2008). Ispol'zovanije biologicheski aktivnyh dobavok $\mathrm{v}$ racione zhivotnyh. Kormlenije sel'skohozjajstvennyh zhivotnyh i kormoproizvodstvo. 9, 9-10 (in Russian).

Dolec'kyj, S. (2007). Stan mineral'nogo obminu v organizmi laktujuchyh koriv zahidnoi' geohimichnoi' zony Ukrai'ny. Veterynarna medycyna Ukrai'ny. 8, 25-28 (in Ukrainian).

Dolec'kyj, S.P. (2013). Vplyv kormovoi' dobavky Pankorm na bilkovyj ta mineral'nyj obmin u laktujuchyh koriv za suchasnyh ekologichnyh umov. Veterynarna biotehnologija. 22, 144-147 (in Ukrainian).

Dresler, S., Illek, J, Zeman, L. (2016). Effects of organic zinc supplementation in weaned calves. ACTA VET. BRNO. 85, 049-054.

Grygorjeva, G.S., Kyrychok, L.M., Konahovych, N.F. (1998). Kompleksoutvorennja yak sposib pidvyshhennja neshkidlyvosti spoluk mikroelementiv. Sovrjemennyje problemy toksykologii’. 1, 21-23 (in Ukrainian).

Gurskyj, R. (2006). Mikroelementozna nedostatnist' u Zahidnyh biogeohimichnyh provincijah IvanoFrankivs'koi' oblasti ta metody i' korekcii'. Veterynarna medycyna Ukrai'ny. 3, 36-38 (in Ukrainian).

Kebec, A.P., Kebec, N.M. (1998). Smeshano-ligandnyje sojedinjenija biometalov s vitaminami i aminokislotami i perspektiva ih primenjenija $\mathrm{v}$ zhivotnovodstve. 
Teorija i praktika ispol'zovanija biologicheski aktivnyh veshhestv $\mathrm{v}$ zhivotovodstve: $\mathrm{X}$ Tez. dok. nauch. konf. Kirov, 37-38 (in Russian).

Kinal, S., Korniewicz, A., Jamroz, D. (2005). Dietary effects of zinc, copper and manganese chelates and sulphates on dairy cows. J. Food Agric. Environ. 3 (1), 168-172.

Kljuchkovs'ka, M.V. (2004). Gemopoez, obmin bilkiv, vmist mikroelementiv ta mjasna produktyvnist' vidgodivel'nyh bugajciv za vplyvu biologichno aktyvnyh rechovyn. Nauk. visnyk LNAVM im. S.Z. G'zhyc'kogo. L'viv, 7(2), 5, 27-31 (in Ukrainian).

Koltun, Ye.M., Rusyn, V.I. (2016). Kliniko-biohimichnyj status dijnyh koriv PAF «Nefedivs'ke» Kamjanec'Podil's'kogo rajonu Hmel'nyc'koi' oblasti. Nauk. visnyk LNUVM ta BT im. S.Z. G'zhyc'kogo. L'viv, 18, 3(71), 37-40 (in Ukrainian). doi: http://dx.doi.org/10.15421/nvlvet7108.

Koltun, Ye.M., Rusyn, V.I. (2014). Profilaktyka hipomikroelementoziv molodnjaka hudoby $\mathrm{v}$ umovah VAT "Dubnohmil"”. Nauk. visnyk LNUVM ta BT im. S.Z. G'zhyc'kogo. L'viv, 16, 3(60), 152-158 (in Ukrainian).

Kravciv, R.Y., Usachenko, L.M., Kovaliv, L.M. (2008). Vplyv deficytnyh mikroelementiv $u$ formi mineral'nyh solej abo helatnyh spoluk (metionativ) na organizm tvaryn ta yihni produktyvni yakosti. Nauk. visnyk LNUVMBT im. S.Z. G'zhyc'kogo. L'viv, 10, 4(39), 119-125 (in Ukrainian).

Kuchinskij, M.P. (2007). Bioelementy - factor zdorovja i produktivnosti zhivotnyh: monografija. Minsk: Biznesofset (in Russian).

Kuznecov, S.G., Kalashnik, V.I. (2002). Effektivnost' ispol'zovanija premiksov v kormljenii' dojnyh korov. Zootehnija. 2, 14-18 (in Russian).

Lowel, J.A., Wiseman J., Cole, D.J.A. (1994). Absorption and retention of zinc when administered as an aminoacid chelate in the dog. Journal of Nutrition. 124, 2572-2574.

Mel'nychenko, O.M., Gerasymenko, V.G. (1994). Oderzhannja helatokompleksnyh spoluk biogennyh metaliv z metoju vykorystannja i'h u tvarynnyctvi. Nauk.-prak. konf. «Vcheni Bilocerkivs'kogo derzhavnogo sil's'kohospodars'kogo instytutu». Tezy dop. Bila Cerkva, 154 (in Ukrainian).

Skyba, O.O., Golopura, S.I., Grushans'ka, N.G. (2009). Vplyv preparatu «Stymtel» na pokaznyky aktyvnosti transaminaz krovi suhostijnyh koriv. Nauk. visnyk LNUVM ta BT im. S.Z. G'zhyc'kogo. L'viv, 11, 3, 140-144 (in Ukrainian).

Slivins'ka, L. (2008). Vmist kobal'tu i midi v krovi ta stan erytrocytopoezu za anemii' u Zahidnomu regioni Ukrai'ny pry zastosuvanni preparatu «MIKROLAKT». Sil's'kyj gospodar. 11-12, 31-34 (in Ukrainian).

Sudakov, M.O., Bereza, V.I., Pogurs'kyj, I.G. (1995). Mikroelementozy u sil's'kogospodars'kyh tvaryn na Ukrai'ni. Mater. nauk. - vyrob. konf. «Aktual'ni pytannja veterynarnoi' medycyny». K., 124-125 (in Ukrainian).

Tako, E., Ferket, P.R., Uni, Z. (2004). Zinc-methionine enhances the intestine development and functionality in the late term embryos and chicks. Poultry Science. 83, 267.

Vlizlo, V.V., Sologub, L.I., Yanovych, V.G. (2006). Biohimichni osnovy normuvannja mineral'nogo zhyvlennja velykoi' rogatoi' hudoby. Mikroelenty. Biologija tvaryn. 8, 1-2, 43-54 (in Ukrainian).

Yefimov, V.G. (2004). Vmist zagal'nogo bilka ta bilkovyh frakcij syrovatky krovi laktujuchyh koriv pid vplyvom gidrogumatu ta mikroelementiv. Nauk. visnyk LNAVM im. S.Z. G'zhyc'kogo. L'viv, 6, 3, 3, 52-56 (in Ukrainian).

Zaharenko, M., Shevchenko, L., Myhal'ska, V. (2004). Rol' mikroelementiv u zhyttjedijal'nosti tvaryn. Veterynarna medycyna Ukrai'ny. 2, 13-16 (in Ukrainian). Received 22.09.2017 Received in revised form 20.10.2017 Accepted 24.10.2017 